\title{
The Economic Losses of Surra Outbreak in Sumba Timur, Nusa Tenggara Timur-Indonesia
}

\author{
R. S. Dewi ${ }^{a}$, R. Damajanti ${ }^{b, *}$, A. H. Wardhana ${ }^{c}$, S. Mulatsih ${ }^{d}$, O. N. Poetri ${ }^{b}$, W. Steeneveld $^{\mathrm{e}}$, \& H. Hogeveen $^{\mathrm{f}}$ \\ ${ }^{a}$ Veterinary Public Health, IPB Postgraduate School, IPB University (Bogor Agricultural University) \\ Department of Animal Diseases and Veterinary Health, Faculty of Veterinary Medicine, IPB University \\ (Bogor Agricultural University) \\ 'Department of Parasitology, Indonesian Research Center for Veterinary Sciences \\ Jalan R.E Martadinata No. 30, Kotak Pos 151, Bogor 16124, Jawa Barat, Indonesia \\ ${ }^{\mathrm{d} D e p a r t m e n t ~ o f ~ E c o n o m i c ~ S c i e n c e, ~ F a c u l t y ~ o f ~ E c o n o m i c s ~ a n d ~ M a n a g e m e n t, ~ I P B ~ U n i v e r s i t y ~}$ \\ (Bogor Agricultural University) \\ Kampus IPB Darmaga, Bogor16680, Jawa Barat, Indonesia \\ eDepartment of Farm Animal Health, Faculty of Veterinary Medicine, Utrecht University \\ Yalelaan 7, 3508 TD Utrecht, The Netherlands \\ ${ }^{\mathrm{f} B u s i n e s s}$ Economics Group, Wageningen University \\ Hollandseweg 1, 6700EW Wageningen, The Netherlands \\ *Corresponding author: retnodmail@yahoo.com \\ (Received 19-06-2019; Revised 27-08-2019; Accepted 18-09-2019)
}

\begin{abstract}
Surra or trypanosomiasis outbreak occurred at Sumba Timur in 2010. Investigating the economic impact of an outbreak of Surra, especially in areas that were free of Surra before, has never been performed in Indonesia. The overall aims of this research are to analyze the economic impact of the Surra outbreak between 2010 and 2016 in Sumba Timur using a modified formula. Total economic losses were calculated by the sum of direct cost, indirect cost, and the other expenditure cost using primary and secondary data. Primary data were collected from interviews with 30 farmers, selected by multistage random sampling and from 2 livestock services officers. Secondary data were collected from The Livestock Services of Sumba Timur and The Diseases Investigation Center in Denpasar and The Local Quarantine Agency of Kupang. The result showed that the total economic loss caused by Surra was IDR (Indonesian Rupiah) 25.7 billion. The highest cost was indirect costs $(46 \%)$, followed by the direct cost $(37 \%)$ and control expenditure (17\%). The highest proportion of the costs occurred in the years of 2011 and 2012, when the Surra outbreak started and when there was no control program in place. From the total of government expenditure related to the Surra outbreak, $64 \%$ of the total costs were part of the epidemic response program. The costs of prevention (maximal IDR 3.24 billion in 2013) were estimated to be lower than the costs of an outbreak (maximal IDR 5.04 billion in 2012). The high cost of outbreak was caused by the absence of a control program in place and the lack of knowledge of farmers about Surra diseases at the beginning of outbreak.
\end{abstract}

Keywords: direct cost; indirect cost; control expenditure economic impact; Surra

\section{INTRODUCTION}

Trypanosoma evansi (T. evansi) is widely distributed in the tropical and subtropical areas in Asia, Africa, and South America (Luckins \& Dwinger, 2004; Powar et al., 2006). It causes a disease called Surra. The principal host species of this disease varies geographically, but camels, horses, buffaloes, and cattle are particularly affected, eventhough the other animals, including wildlife, are also susceptible. Surra is an arthropod-borne disease; several species of hematophagous flies, including Tabanids and stomoxis, are implicated in the mechanical transfer of infection from host to host (OIE, 2012; Baldacchino et al., 2013; Baldacchino et al., 2014). Surra causes fever, anemia, weakness, and nervous symptoms.
This disease is responsible for major production losses (meat, milk, draught power, fertility, and manure), leading to cachexia and sometimes abortion and/ or death if left untreated (Desquesnes et al., 2013; Derakhshanfar et al., 2010).

T. evansi was presumed to arrive in South East Asia through the import of livestock from India (Payne et al., 1991). In the early years of the nineteenth century, devastating Surra epidemics affected the Philippines, Mauritius, India, and Indonesia. More recent infection rates in Indonesia vary considerably, depending on the detection methods, and vary between $1.4 \%$ and $6 \%$ in cattle and between $5.8 \%$ and $7 \%$ in buffaloes on Sumatra, Java, South Kalimantan, Lombok, South Sulawesi, and North Sulawesi (Partoutomo, 1995). The 
serological study by Payne et al. (1991), concludes that T. evansi has reached an endemic status throughout Indonesia.

Sumba island is part of the province of Nusa Tenggara Timur and is divided into four districts: Sumba Barat, Sumba Barat Daya, Sumba Tengah, and Sumba Timur. Until 2009, Sumba island was declared as a Surra free area. In 2010, however, Surra was introduced onto Sumba island via livestock traffic (report of Disease Investigation Center of Denpasar 2010). The ensuing epidemic resulted in the death of livestock between 2010 and 2012 (672 horses and 148 water buffaloes) (report of the Livestock Service of Sumba Timur), and the livestock population (31,048 horses and 37,052 water buffaloes) is still at risk. Although the local animal health authorities took measures to control the outbreak of Surra in Sumba Timur, the cost-effectiveness of these actions is unclear.

Quantitative information on the impact of Surra is limited. Besides costs for treatment, the impacts of Surra can include changes in the animal population, economic losses for animal owners (tangible effects), as well as social consequences for animal owners (intangible effects). The economic losses due to Surra are high (Desquesnes et al., 2013) because it causes high mortality, lower milk and meat production, lower carcass quality, decreased reproductive performance, decreased fertilizer production, and has immunosuppressive properties. Preventive or control programs for indirect losses, for example, costs for preventive treatment and surveillance costs, also account for economic losses (Rushton et al., 1999). Investigating the economic impact of a Surra outbreak, especially in the areas which were previously Surra free, has never been performed for Indonesia. Insight into the economic impact of Surra and the effectiveness of the control of the disease during the outbreak in Sumba in 2010 , it can act as a good evaluation of the past control program as well as providing a starting point for improved future programs.

The overall aim of this research is to analyze the economic impact of the Surra outbreak between 2010 and 2016 in Sumba Timur. Also, the cost-effectiveness of the Surra control measures provided by the animal health authorities was evaluated.

\section{MATERIALS AND METHODS}

\section{Data Collection}

Study area. The study was conducted in the Sumba Timur region, Nusa Tenggara Timur Province. Primary data were collected from interviews with 30 farmers who were affected by the Surra outbreak in 2010-2013 and selected by Stratified Random Sampling. In total 19 out of 22 districts were affected by the outbreak, and for this data collection, five districts were chosen randomly (Pahunga Lodu, Rindi, Wulla Wajelu, Lewa, Lewa Tidahu). In each district, two villages were randomly selected, and 2 until 4 farmers in these villages were visited.
Study design. This study used primary and secondary data. Primary data were collected by interviewing the farmers and the interview was conducted in May 2017, for which a questionnaire was developed. The questionnaire included all kinds of questions on the Surra outbreak, but for this research, only the questions on production loss (the decrease in body weight), price of livestock, vector control, and extermination of the dead animals were used. All farmers had horses and/or water buffaloes, and the questions were focused on these animals. The interviews with the farmers were carried out by a veterinarian officer. A retailer was asked to provide information about the price on the laboratory equipments and drugs. The Sumba Timur livestock services provided information on the laboratory diagnostics, drugs, the daily capacity of one officer to carry out the treatment and take blood samples, and the estimation on the proportion of racehorses in the total horse population.

The secondary data were collected from the Sumba Timur livestock services reports, The Diseases Investigation Center (DIC) in Denpasar and The Local Quarantine Agency of Kupang (Annual report book). The data obtained on horses and water buffaloes for the 2010-2016 period included the number of animal deaths (mortality), the number of sick animals (morbidity), the number of animals per infected farm, the number of laboratory samples that were tested in total, and the number of quarantined livestock.

Livestock prices were obtained from farmer questionnaire data, based on the minimum and maximum prices of various averaged cattle ages. The mortality, morbidity, and herd population information such as type of livestock, age, and sex were not recorded on the report of Sumba Timur Livestock Services. The technical and economic parameters were presented in Table 1 and 2.

\section{Calculation of Economic Impact}

The framework presented in Figure 1, which was adapted from the framework of Rushton et al. (1999), was developed in order to calculate the economic impact of the Surra outbreak between 2010 and 2016. In this framework, the total economic impact was the sum of the direct costs, the indirect costs, and the control expenditures.

The direct costs were defined as costs that had an immediate impact on the owner (the number of dead animals, production losses, and the cost of curative treatment paid for by the owner). Indirect costs were defined as disease prevention costs (costs of preventive treatment, surveillance costs, and costs for monitoring the disease by laboratory diagnosticians). Disease control expenditures included the costs of implementing four control measures: 1) livestock traffic control, 2) vector control, 3) public awareness, and 4) extermination costs.

To control Surra, the Regent of Sumba Timur issued Decree of Regent No: 185.Disnak.524.3/570/ VII/2010 and Instruction of Regent No: 147 of 2010 in July on the emergency response from Surra threat in 
Table 1. Data used to calculate the direct costs for the outbreak of Surra in Sumba Timur between 2010 and 2016

\begin{tabular}{|c|c|c|c|c|}
\hline Description & Abbreviation & Value & Unit & $\begin{array}{c}\text { Source of } \\
\text { information }\end{array}$ \\
\hline \multicolumn{5}{|l|}{ Mortality Costs } \\
\hline Sumba horse price & $\mathrm{Ph}$ & $5,900,000$ & IDR/animal & Farmer \\
\hline Racing horse price & Prh & $20,000,000$ & IDR/animal & Farmer \\
\hline Water buffalo price & $\mathrm{Pb}$ & $9,000,000$ & IDR/animal & Farmer \\
\hline Number of dead horses & Ndh & 700 & 2010-2016 & Livestock services \\
\hline Racing horse proportion & Rhp & 10 & Percentage & Livestock services \\
\hline Number of dead water buffaloes between 2010-2016 & $\mathrm{Ndb}$ & 178 & 2010-2016 & Livestock services \\
\hline \multicolumn{5}{|l|}{ Cost of production loss } \\
\hline Horses production loss proportion & Pph & 30.6 & $\%$ & Farmer \\
\hline Water buffaloes production loss proportion & $\mathrm{Ppb}$ & 29.4 & $\%$ & Farmer \\
\hline Number of sick horses between 2010-2016 & $\mathrm{Nih}$ & 565 & & Livestock services \\
\hline Number of sick water buffaloes 2010-2016 & $\mathrm{Nib}$ & 221 & & Livestock services \\
\hline \multicolumn{5}{|l|}{ Cost of curative treatment } \\
\hline Price of Tryphonyl & Ptryp & 135,000 & IDR/sachet & Livestock services \\
\hline Price of Trypamidium & PTrypa & 250,000 & IDR/sachet & Livestock services \\
\hline Number of horses in infected region & Nhi & 37,561 & 2010-2016 & Livestock services \\
\hline Number of water buffaloes in infected region & $\mathrm{Nbi}$ & 27,191 & 2010-2016 & Livestock services \\
\hline Treatment officer transport cost & Ctrans & 116,000 & IDR/person & Livestock services \\
\hline Syringe & Psy & 2500 & IDR/animal & Retailer \\
\hline Treating capacity & Tc & 20 & animal/person/day & Livestock services \\
\hline $50 \mathrm{~mL}$ distilled water price & $\mathrm{Pw}$ & 5,000 & IDR/bottle & Retailer \\
\hline Alcohol and cotton price & Palk & 200 & IDR/animal & Retailer \\
\hline
\end{tabular}

Note: ${ }^{c}=$ Livestock services are local government authority for animal health in Sumba Timur; Retailer are the laboratory material seller; Farmer are the person which rearing livestock (Respondent); Quarantine are the local quarantine agencys of Sumba Timur.

Sumba Timur region in 2010. There were some steps to prevent Surra transmission, for example by controlling the parasite and controlling the vector (Singh \& Singla, 2015). To reduce Surra cases in East Sumba, the local government conducted controlling and monitoring programs such as treatment (curative and preventive), surveillance and monitoring, laboratory diagnostics, livestock traffic control, vector control, public awareness program and extermination of dead animals.

\section{Direct Costs}

Mortality costs (Cmort) (2) were calculated by multiplying the number of dead livestock ( $\mathrm{Ndh}, \mathrm{Ndb})$ with the price of livestock $(\mathrm{Ph}, \mathrm{Pb})$ :

Cmort $=(\mathrm{Ndh} \times \mathrm{Ph})+(\operatorname{Rhp} \times \mathrm{Prh})+(\mathrm{Ndb} \times \mathrm{Pb})$.

Decreased production costs (Cprod) (3) were calculated by multiplying the number of sick livestock (Nih) with the average percentage production loss per animal (Dprod) and the price of livestock (Ph). The average percentage production loss was calculated based on the production loss in $\mathrm{kg}$ provided by the 30 farmers in the questionnaire $\mathrm{Cprod}=(\mathrm{Nih} \times \mathrm{Ph} \times \mathrm{Pph})+(\mathrm{Nib} \times \mathrm{Pb} \times$ $\mathrm{Ppb})$.

The costs of curative treatment (Cct) (4) were calculated by multiplying the number of sick livestock $(\mathrm{Nih}+\mathrm{Nib})$ with the costs of curative treatment (twice for the administration of Tryphonil ${ }^{\circledR}$ (Diminazene aceturate) (Ptryp) and twice for the administration of Trypamidium ${ }^{\circledR}$ (Isometamidium) (Ptrypa). The calculation included the transportation costs of an officer
(Ctrans) with the capacity to treat 20 animals per day. Also the price of syringes, alcohol, and distilled water that was used for the application of the treatment (Psy, Palk, Pw) were calculated.

$\mathrm{Cct}=((\mathrm{Nih}+\mathrm{Nib}) \times$ Ptryp $\times 2)+((\mathrm{Nih}+\mathrm{Nib}) \times$ Ptrypa $\times 2)$ $+((\mathrm{Nih}+\mathrm{Nib}) \times(\mathrm{Psy}+\mathrm{Palk}+\mathrm{Pw}))+((\mathrm{Nih}+\mathrm{Nib}) / \mathrm{Tc}) \mathrm{x}$ Ctrans)

\section{Indirect Costs}

The costs of preventive treatment (Cpt) (5) were calculated by multiplying the number of all livestock on the farm $(\mathrm{Nhr}+\mathrm{Nbr})$ by the costs of treating them with Trypamidium ${ }^{\circledR}$ (Ptrypa) three times a year (personal communication with the officer of The Livestock Services in Sumba Timur). The calculation included the transportation costs of an officer with a capacity to treat 20 animals per day (Ctrans) and calculated the price of syringes, alcohol, and distilled water that we used for the application of the treatment (Psy, Palk, Pw).

$\mathrm{Cpt}=(\mathrm{Nhr}+\mathrm{Nbr}) \times(($ Ptrypa $\times 3)+((\mathrm{Nhr}+\mathrm{Nbr}) \times($ Psy + $\mathrm{Palk}+\mathrm{Pw}))+((\mathrm{Nhr}+\mathrm{Nbr}) / \mathrm{Tc} \times$ Ctrans $)$

Surveillance costs (Csurv) (6) were the costs related to the surveillance and monitoring of Surra in Sumba Timur. The surveillance was conducted by The Livestock Services Office of Sumba Timur (Cgov) and DIC in Denpasar (CBvet). The costs included the transportation costs (Ctor, Ctrans) of the officer visiting the farm and the collection of blood samples (Nsm) (one officer could take 10 blood samples per day). 
Table 2. Data used to calculate the indirect costs and control expenditure for the outbreak of Surra in Sumba Timur between $2010-2016$

\begin{tabular}{|c|c|c|c|c|}
\hline Description & Abbreviation & Value & Unit & $\begin{array}{c}\text { Source of } \\
\text { information }\end{array}$ \\
\hline \multicolumn{5}{|l|}{ Cost of preventive treatment } \\
\hline Price of Trypamidium & PTrypa & 250,000 & IDR/sachet & Livestock services \\
\hline Number of horses in infected region & Nhr & 37,561 & 2010-2016 & Livestock services \\
\hline Number of water buffaloes in infected region & $\mathrm{Nbr}$ & 27,191 & $2010-2016$ & Livestock services \\
\hline Treatment officer transport cost & Ctrans & 116,000 & IDR/person & Livestock services \\
\hline Syringe & Psy & 2500 & IDR/animal & Retailer \\
\hline Treating capacity & Tc & 20 & animal/person & Officer \\
\hline $50 \mathrm{~mL}$ Distilled water price & $\mathrm{Pw}$ & 5,000 & IDR/bottle & Retailer \\
\hline Alcohol and cotton price & Palk & 200 & IDR/animal & Retailer \\
\hline \multicolumn{5}{|l|}{ Surveillance and monitoring cost } \\
\hline DIC officer transport and accommodation cost & Ctor & $7,000,000$ & Person/event & DIC of Denpasar \\
\hline Cost of local transportation & Ctrans & 116,000 & Person/event & Livestock services \\
\hline Sampling capacity & Sc & 10 & Sample/person & Livestock services \\
\hline Number of samples taken between 2010-2016 & Nsm & 72664 & unit & Livestock services \\
\hline \multicolumn{5}{|l|}{ Laboratory diagnostic cost } \\
\hline Slide glass price & Psg & 750 & IDR/sample & Merchant \\
\hline Other (ethanol, giemsa, immersion oil, tissue) & Po & 3,250 & IDR/sample & Merchant \\
\hline Number of samples taken between 2010-2016 & Nsm & 72,664 & 2010-2016 & Livestock services \\
\hline \multicolumn{5}{|l|}{ Livestock traffic control cost } \\
\hline Animal health examination cost & Cat & 15,000 & IDR/animal & Livestock services \\
\hline Number of transported horses & Nth & 21,988 & Animal & Livestock services \\
\hline Number of transported buffaloes & $\mathrm{Ntb}$ & 12,704 & Animal & Livestock services \\
\hline \multicolumn{5}{|l|}{ Animal quarantine cost } \\
\hline Number of quarantined horses & $\mathrm{Nqh}$ & 25,261 & Animal & Quarantine \\
\hline Number of quarantined water buffaloes & $\mathrm{Nqb}$ & 11,493 & Animal & Quarantine \\
\hline Horse feed price & Hfp & 40,000 & IDR & Quarantine \\
\hline Water buffalo feed price & $\mathrm{Hbp}$ & 80,000 & IDR & Quarantine \\
\hline Non-tax payment for quarantine (2010-2016) & $\mathrm{Ntg}$ & $291,167,401$ & IDR & Quarantine \\
\hline Animal care service costs & Acs & 40,000 & IDR/animal & Quarantine \\
\hline \multicolumn{5}{|l|}{ Vector control cost } \\
\hline Number of horses in infected region (2010-2016) & Nhi & 37,561 & Animal & Livestock Services \\
\hline Number of water buffalo in infected region (2010-2016) & $\mathrm{Nbi}$ & 27,191 & Animal & Livestock Services \\
\hline Price of insecticide & Pins & 50,000 & bottle & Livestock Services \\
\hline Public awareness costs & Cpa & $20,000,000$ & IDR/year & Livestock services \\
\hline \multicolumn{5}{|l|}{ Extermination cost } \\
\hline Cost for extermination & $\mathrm{Cft}$ & 100,000 & IDR/animal & Farmers \\
\hline Number of dead horses $\quad(2010-2016)$ & $\mathrm{Ndh}$ & 700 & animal & Livestock Services \\
\hline Number of dead water buffaloes (2010-2016) & $\mathrm{Ndb}$ & 178 & animal & Livestock Services \\
\hline
\end{tabular}

Note: ${ }^{c}=$ Livestock services are local government authority for animal health in Sumba Timur; Retailer are the laboratory material seller; Farmer are the person which rearing livestock (Respondent); Quarantine are the local quarantine agencys of Sumba Timur.

$$
\begin{aligned}
& \text { Csurv }=(\text { CBvet }+ \text { Cgov }) \\
& \text { CBvet }=3 \text { person } \times \text { Ctor } \times 3 \text { (/year }) \\
& \text { Cgov }=\text { Nsm } / 10 \times \text { Ctrans }
\end{aligned}
$$

Laboratory diagnostic costs (CLab) (7) were the costs of Surra diagnostic tests using stained thin smears (Slide glass price (Psg) and, ethanol giemsa immersion oil tissue (Po).

$$
\mathrm{Clab}=(\mathrm{Nsm}) \times(\mathrm{Psg}+\mathrm{Po}) .
$$

\section{Expenditures on Controlling the Disease}

Livestock traffic control costs (Cat) (8) were costs related to controlling livestock import and export between regions or islands. Monitoring livestock traffic within Sumba islands was conducted by the Sumba Timur Livestock Services Office (Catl), while monitoring import/export traffic between different islands was conducted by the Indonesian Agricultural Quarantine Agency (Caq). The cost for checking animals in Livestock Services was IDR (Indonesian Rupiah) 15,000/ animal. For the quarantine traffic control cost, the calculated cost were costs paid to the government as non-tax state revenues (Ntg) and animal care service cost (Acs), and feed cost (IDR 40,000 for horses and IDR 80,000 for water buffaloes).

$$
\text { Cat }=\text { Catl }+ \text { Caq }
$$




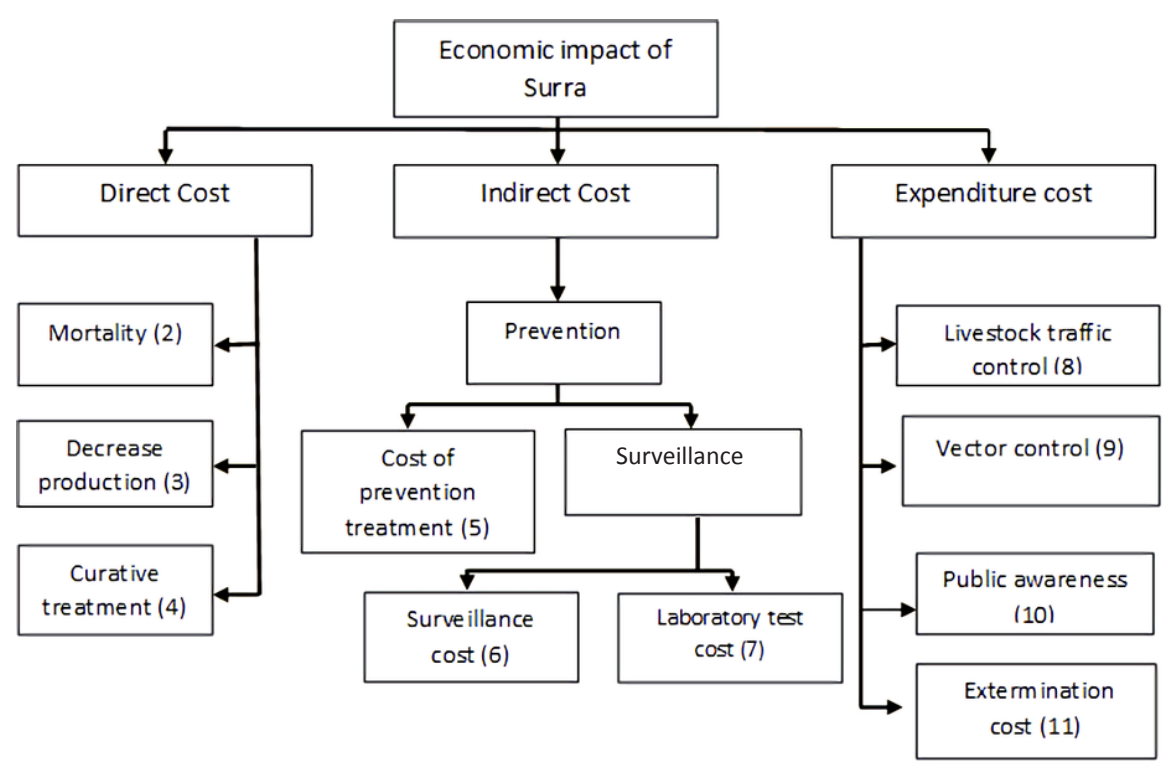

Figure 1. Framework to calculate the economic impact of Surra. The framework was adapted from Rushton et al. (1999). The total economic impact is calculated as the sum of direct cost, indirect costs, and control expenditures.

Catl $=(\mathrm{Nth}+\mathrm{Nbh}) \times$ IDR $15,000.00$

$\mathrm{Caq}=\mathrm{Ntg}+((\mathrm{Nqh}+\mathrm{Nqb}) \times \mathrm{Acs}+((\mathrm{Nqh})) \times \mathrm{IDR}$ $40,000))+(\mathrm{Nqb} \times$ IDR 80,000))

Vector control costs (Cvec) (9) were costs related to insecticide sprays to control flies as a vector of Surra. The calculation was based on information given by the farmers in the questionnaire that one bottle of insecticide (Pins) could be used for 200 animals.

Cvec $=((\mathrm{Nhr}+\mathrm{Nbr}) \times($ Pins $) / 200$ head.

Public awareness costs (Cpa) (10) were the costs related to organizing events to increase public knowledge about Surra.

Cpa = IDR 20,000.000/year

The extermination costs (Cextr) (11) were the costs related to destroying the dead livestock. The average cost of exterminating one animal, as provided by the farmers in the questionnaire, was 100,000 IDR.

Cext $=(\mathrm{Ndh}+\mathrm{Ndb}) \times \operatorname{IDR} 100,000)$

The control program of Surra included curative treatment, preventive treatment, surveillance and monitoring, laboratory diagnostics, livestock traffic control, vector control, public awareness program, and extermination of dead animals.

\section{RESULTS}

The prevalence of mortality and morbidity of horses and water buffaloes due to Surra during 2010-2016 at Sumba Timur are presented in Table 3. The highest mortality and morbidity due to Surra infection was in the year of 2010, in which the first outbreak of Surra in Sumba Timur occurred. The mortality rate of horses reached $7.6 \%$ in 2010 and reached $2.7 \%$ for water buffaloes in 2011. The morbidity rate of horses reached $11.27 \%$ in 2010 and $7.1 \%$ for water buffaloes in 2011.

The economic impact of Surra during 2010-2016 in Sumba Timur was quantified by calculating direct costs, indirect costs, and the other control expenditures cost as presented in Table 4. Results showed that during 2010-2016, the indirect costs (IDR 11.7 Billion/US\$ equal to 818,282$)(46 \%$ of the total costs) were higher than the direct costs (IDR 9.5 Billion/US\$ 660,251 (37\% of the total costs)), and control expenditures costs (IDR 4.4 Billion/ US\$ 309,694 (17\% of the total costs)). Annual costs are presented in Table 5 and Figure 2, and it can be noticed that the total costs of Surra increased over time and reached the highest level in 2012. After that the total costs decreased. The year with the highest economic impact (2012) was the year with the highest direct cost

Table 3. Surra prevalence, mortality, and morbidity in Sumba Timur (for the years of 2010-2016 for horses and water buffaloes)

\begin{tabular}{|c|c|c|c|c|c|}
\hline \multirow{2}{*}{ Year (\%) } & \multirow{2}{*}{ Prevalence } & \multicolumn{2}{|c|}{ Mortality (\%) } & \multicolumn{2}{|c|}{ Morbidity (\%) } \\
\hline & & Horse & Water buffalo & Horse & Water buffalo \\
\hline 2010 & 13.6 & 7.6 & 0 & 11.27 & 1.07 \\
\hline 2011 & 8.17 & 3.5 & 2.7 & 8.3 & 7.1 \\
\hline 2012 & 5.3 & 4.5 & 1.5 & 8.4 & 2.8 \\
\hline 2013 & 0.42 & 0.16 & 0 & 0.65 & 0.2 \\
\hline 2014 & 0.50 & 0.09 & 0 & 0.6 & 0.23 \\
\hline 2015 & 0.32 & 0 & 0 & 0.32 & 0.36 \\
\hline 2016 & 1.15 & 0.17 & 0 & 1.06 & 0.9 \\
\hline
\end{tabular}

Source: The local livestock services years annual report (2010-2016). 
and considerable preventive cost, which apparently was not affecting yet. In the years after 2012, the direct cost steeply decreased while the preventive costs follow later.

\section{DISCUSSION}

\section{Development of Surra Control}

Sumba was initially a Surra-free area. In early June 2010, the first Surra cases in horses and water buffaloes were detected in Sumba Barat, causing the death of 19 out of 48 sick horses and 33 out of 67 sick water buffa-

Table 4. Economic impact of Surra during the period 2010-2016 in Sumba Timur

\begin{tabular}{|c|c|c|}
\hline Type of cost & Total (IDR) ${ }^{\mathrm{a}}$ & $\begin{array}{l}\text { Percentage } \\
\text { of economic } \\
\text { impact }(\%)\end{array}$ \\
\hline \multicolumn{3}{|l|}{ Direct costs } \\
\hline Mortality costs & $7,069,000,000$ & 27 \\
\hline Decrease of production loss & $2,146,437,000$ & 8 \\
\hline Curative treatment costs & $283,606,000$ & 1 \\
\hline Sub total & $9,499,043,000$ & 37 \\
\hline \multicolumn{3}{|l|}{ Indirect costs } \\
\hline Cost of preventive treatment & $10,198,077,000$ & 40 \\
\hline $\begin{array}{l}\text { Cost of laboratory } \\
\text { examination }\end{array}$ & $290,656,000$ & 1 \\
\hline $\begin{array}{l}\text { Cost of surveillance and } \\
\text { monitoring }\end{array}$ & $1,283,902,400$ & 5 \\
\hline Sub total & $11,772,635,400$ & 46 \\
\hline \multicolumn{3}{|l|}{ Control expenditures } \\
\hline $\begin{array}{l}\text { Cost of animal traffic } \\
\text { monitoring }\end{array}$ & $4,211,587,401$ & 16 \\
\hline Cost of vector control & $16,188,000$ & 0 \\
\hline Public awareness costs & $140,000,000$ & 1 \\
\hline Cost of extermination & $87,800,000$ & 0 \\
\hline Sub total & $4,455,575,401$ & 17 \\
\hline Total & $25,727,253,801^{\mathrm{b}}$ & \\
\hline
\end{tabular}

aIDR is Indonesian rupiahs, Indonesian currency, 1 US $\$=$ IDR 14,387 (per 4 February 2019); ${ }^{\mathrm{b} T o t a l}$ US $\$ 1,788,299.2$ loes. Further investigation by the Disease Investigation Center (DIC) in Denpasar gave positive test results for Surra in 24 of the 65 samples taken $(36.9 \%)$. The introduction of Surra in Sumba occurred when the racing horses were transported from Bima-Nusa Tenggara Barat to Sumba Barat. In July 2010, it was confirmed that there was a Surra outbreak amongst the horses and water buffaloes in Sumba Barat, and the first outbreak of Surra in Sumba Timur occurred in August 2010.

At the peak of the outbreak, the mortality rate reached $7.6 \%$ in horses (2010) and $2.7 \%$ in water buffaloes (2011) (Table 3). The highest morbidity rate reached $11.27 \%$ in horses (2010) and 7.1\% in water buffaloes (2011) (Table 3). Morbidity and mortality were higher in horses than in water buffaloes because horses are more susceptible to Surra (Desquesnes et al., 2013). Infected water buffaloes often do not show clinical symptoms, though they can be a reservoir of T. evansi and thus be a source of transmission (Mastra 2011).

Table 3 shows that the highest mortality and morbidity rates in horses are occurred in 2010 and the highest mortality and morbidity rates in water buffaloes occurred in 2011. Table 3 also shows the morbidity and mortality rates up to 2016 . The decreased incidence of Surra was induced by the introduction of curative treatment of sick animals and the preventive treatment of animals among the infected group (Giordani et al.,

Table 5. Economic losses per year due to Surra in the period 2010-2016 in Sumba-Timur

\begin{tabular}{cc}
\hline Year & IDR $^{\mathrm{a}}$ \\
\hline 2010 & $1,523,140,100$ \\
2011 & $5,261,048,000$ \\
2012 & $8,743,593,350$ \\
2013 & $4,440,787,700$ \\
2014 & $2,469,283,850$ \\
2015 & $1,503,842,100$ \\
2016 & $1,785,558,701$ \\
Total & $25,727,253,801$ \\
\hline
\end{tabular}

aIDR is Indonesian rupiahs, Indonesian currency, 1 US $\$=$ IDR 14,387 (per 4 February 2019).

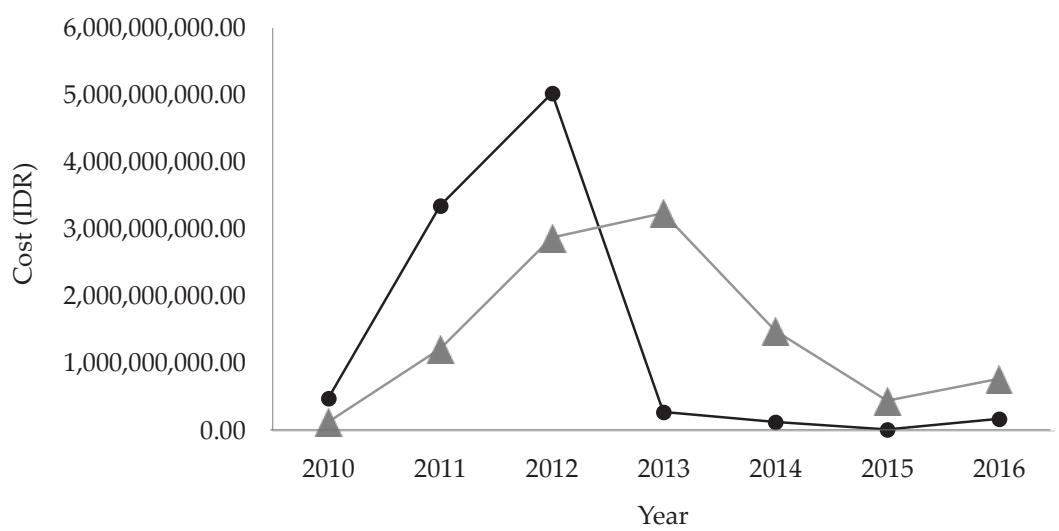

Figure 2. Annual estimated costs of Surra in Sumba Timur during 2010-2016. The direct costs (-๑-) are defined as costs which have an immediate impact on the owner such as the number of dead animals, production losses, and the cost of curative treatment paid by the owner. Preventive costs (- $\mathbf{\Delta}-)$ include the costs of preventive treatment, surveillance cost, and cost for monitoring the disease by laboratory diagnostics. 
2016). In 2010-2011, treatment using Trypamidium ${ }^{\circledR}$ (Isometamidium chloride) was used both as curative and preventive treatments. In 2012-2016, Tryphonyl ${ }^{\circledR}$ (Diminazene aceturate) was used as a curative treatment and Trypamidium ${ }^{\circledR}$ was used as a preventive treatment. The decline in mortality and morbidity was quite sharp after 2012 (Table 3). There were decreases in cases of the disease and deaths to below $1 \%$.

The incidence of infection and death due to Surra in Sumba Timur is believed to be higher than the data shown in Table 3. This difference was since many farmers or animal owners did not report the mortality of their livestock. During data collection, most farmers relied purely on their memory to retrieve mortality and morbidity figures, without consulting any supporting data. Moreover, the laboratory test for the detection of Surra uses a stained blood smear, so it cannot detect subclinically infected animals. To detect subclinically infected animals, more sensitive methods such as polymerase chain reaction (PCR) are highly recommended for Trypanosome detection (Muieed et al., 2010; Ahmed et al., 2013). According to Metanaway-El et al. (2009) at least two laboratory tests are required in detection of Surra (parasitological, serological or molecular tests). Economic aspects can be one of the considerations in choosing a laboratory test method, in addition to the technical aspects (Tejedor- Junco et al., 2011).

The total number of cases of Surra amongst horses and water buffaloes in Sumba Timur was quite high in 2010, 2011, and 2012. After 2012, the number of cases decreased, due to the implementation of the Surra control program by the veterinary service in the region. Treatment for Surra contained curative treatment for sick animals and preventive treatment for susceptible animals. In 2010-2011, both a curative and a preventive treatments using Trypamidium ${ }^{\circledR}$ (Isometamidium chloride) were applied. In 2012-2016, the drugs were changed into Tryphonyl® (Diminazene aceturate) for curative treatment and Trypamidium ${ }^{\circledR}$ for preventive treatment. After changing the drugs, the mortality and morbidity rate is declining (Table 3). The use of diminazene aceturate and isomatemidium chloride in infected animal trypasonomosis area are often such as in Tanzania (Ngumbi \& Silayo, 2017).

Diminazene aceturate is chemocurative for Surra, the first line of treatment in trypanosomosis (Kuriakose \& Uzonna, 2014). According to Akode et al. (2017), Diminazene aceturate is stable, easy to use, and has low toxicity so that it is relatively safe for the animals. Isometamidium chloride provides a longer protection period. It will be up to 4 months at $1.0 \mathrm{mg} / \mathrm{kg} \mathrm{BW}$, so the drug is more suitable for prophylactic treatment of herds in an endemic area. The treatment using a combination of Diminazene aceturate with Isometamidium might be more effective compared to using isometamidium alone. A Previous report demonstrated that Diminazene aceturate and Isometamidium were therapeutically effective against clinical Surra in buffaloes in West Africa (Bengaly et al., 2018).

\section{Economic Losses}

The total economic losses caused by Surra since the beginning of the outbreak in 2010 up to 2016 were IDR 25.7 Billion (Table 4). The economic losses per year are shown in Table 5. Annual economic losses due to Surra in Sumba Timur during 2010-2016 varied between 101,098 US\$ to 586,375 US\$, with the highest losses in 2012. For the other countries, the losses of 158,000 US\$ (Philippines) and 2.4 million US\$ (Brazil) were reported (Desquesnes et al. 2013; Siedl et al. 1998). The difference in economic losses due to Surra in different countries might be due to the difference in livestock population and control programs. Some countries have more livestock than the other countries, and the choice of treatment is different as well (Desquesnes et al., 2013).

Based on the total economic losses, indirect costs give the highest proportion of the impact (46\%). Within the indirect costs, the preventive treatment costs were the highest $(40 \%$ of the total costs) (Table 4$)$. Surra treatments (both preventive and curative) require relatively high costs since the price of the drugs, such as trypanocydal, is expensive (Salifu et al. 2010). A single administration with a curative dose of trypanocydal costs US\$ 4.87-5,23 per animal/year (Sukanto et al., 2000; Muhanguzi et al., 2015). Estimated additional expenditures per household due to a Surra infection is US\$28.23 for preventive treatment and US\$18.2 for curative treatment (Chanie et al. 2013).

The direct costs were responsible for $37 \%$ of the total costs, and within the direct costs, mortality had the highest contribution (27\%) to the total costs. This result is in agreement with the result of an Ethiopian study where mortality also has a relatively high contribution (Chanie et al., 2013).

The costs for preventive treatment are aimed at preventing disease transmission by administering preventive treatment on the whole population. Based on the information from the Sumba Timur Livestock Services Office, the use of preventive treatment was important, since several new cases were reported in 2016 in regions where preventive treatment was discontinued.

In Figure 2, the distribution of prevention costs shows that annual preventive costs are lower than the direct costs. In the present study we quantified the preventive costs like costs for preventive treatment, surveillance costs, and costs for monitoring the disease by laboratory diagnostic and the direct cost were defined as costs which had immediate impact on the owner such as the number of dead animals, production losses, and the costs of curative treatment paid by the owner. The decrease in preventive costs in 2014-2015 seemed to increase the direct costs in the next year. Although it seems logical, causality has not been proven. To do that more information is needed.

Preventive treatment of susceptible non-diseased animals is part of Sumba Timur government programs to prevent an outbreak of Surra. Government expenditures since 2010 have been quite high. These expenditures include the indirect cost, control expenditures, and curative treatment, making a total of IDR 16,4 billion over the years of $2010-2016$ (64\% of the total costs) 
(Table 4). Throughout those years, the incidence of Surra in Sumba Timur stabilized to almost zero, with only sporadic infection taking place. Over the next few years, the governmental contribution to preventive treatments may decrease because, if the disease becomes endemic to Sumba Timur, the government will stop its epidemic response program. If this happens, prevention will become the responsibility of the farmers and might be difficult to maintain because of the shared responsibility. However, until Surra has been completely eradicated, the costs of preventive treatment are well spent since the costs of a major outbreak, as occurred in 2011-2012, are much higher than the preventive costs. The high cost of outbreak was caused by the absence of a control program in place and the lack of knowledge of farmers about Surra diseases at the beginning of outbreak.

\section{CONCLUSION}

The total economic loss caused by Surra between 2010 and 2016 was 25.7 billion IDR. The highest cost was indirect costs $(46 \%)$, followed by the direct cost $(37 \%)$ and control expenditure (17\%). The highest proportion of the costs occurred in the years of 2011 and 2012, when the Surra outbreak started and when there was no control program in place. The government's expenditure related to the outbreak, $64 \%$ of the total costs, was part of the epidemic response program. The costs of prevention (maximal IDR 3.24 billion in 2013) are estimated to be lower than the costs of an outbreak (maximal IDR 5.04 billion in 2012).

\section{CONFLICT OF INTEREST}

The authors declare that there is no conflict of interest with any financial, personal, or other relationships with other people or organization related to the material discussed in the manuscript.

\section{ACKNOWLEDGEMENT}

This work is part of the $\mathrm{PhD}$ Dissertation by the first author and we are grateful to the farmers, The Livestock Services of Sumba Timur and The Disease Investigation Center of Denpasar for their help in providing the data for this study, and the Indonesia Agricultural Quarantine Agency, The Ministry of Agriculture for its financial support.

\section{REFERENCES}

Ahmed, A.H., K. Picozzi, C. Welburn, \& E.T. Macleod. 2013. A comparative evalustion of PCR based methods for species-specific determination of African animal trypanosomes in Uganda cattle. Parasite Vectors 6:1-7. https://doi. org/10.1186/1756-3305-6-316

Akode, R.M., S. W. Shantier, E. A. Gadkariem, \& Mohamed, M.A. 2017. Simultaneous determination and stability studies on diminazene diaceturate and phenazone using developed derivative spectrophotometric method. Int. J. Anal. Chem. vol. 2017, Article ID 4269587, 6 pages, 2017. https://doi.org/10.1155/2017/4269587

Baldacchino, F., V. Muenworn, M. Desquesnes, F. Desoli, T.
Charoenviriyaphap, \& G. Duvallet. 2013. Transmission of pathogens by Stomoxys flies (Diptera, Muscidae): a review. Parasite 20:1-13. https://doi.org/10.1051/parasite/2013026

Baldacchino, F., L. Puech, S. Manon, R. L. Hertzog, \& P. JayRobert. 2014. Biting behaviour of Tabanidae on cattle in mountainous summer pastures, Pyrenees, France, and effect of weather variables. Bull. Entomogical Res. 104:471479. https://doi.org/10.1017/S0007485314000170

Bengaly, Z., S. H. Vitouley, M. B. Somda, A. Zongo, A. TekoAgbo, G. Cecchi, Y. Adam, I. Sidibe, B. Bayala, A. M. GastonBelem, J. V. D. Abebeele, \& V. Delespaux. 2018. Drug quality analysis of isometamidium chloride hydrochloride and diminazene diaceturate used for the treatment of African animal trypanosomosis in West Africa. BMC Vet. Res. 14:1-8. https://doi.org/10.1186/s12917-018-1633-7

Chanie, M., D. Adula, \& B. Bogale. 2013. Socio-Economic assassment of the impacts of trypanosomiasis on cattle in Girja District, Southern Oromia Region, Southern Ethiopia. Acta Parasitol. Globalis. 4:80-85.

Derakhshanfar, A., A. A. Mozaffari, \& M. Zadeh. 2010. An outbreak of trypanosomiasis (Surra) in Camels in Southern Fars Provonce of Iran: Clinical, Hematology and Pathological findings. Res. J. Parasitol. 5:23-36. https://doi. org/10.3923/jp.2010.23.26

Desquesnes, M., A. Dargantes, D. Lai, Z. R. Lun, P. Holzmuller, \& S. Jittapalapong. 2013. Trypanosoma evansi and Surra: a review and perspectives on transmission, epidemiology and control, impact, and zoonotic aspects. BioMed Res. Int. vol. 2013, Article ID 321237, 20 pages, 2013. https://doi. org/10.1155/2013/321237

Giordani, F., L. J. Morrison, T. G. Rowan, P. Harry, De Koning, M. P. Barret. 2016. The animal trypanosomiases and their chemotherapy: a riview. Parasitology 143:1862-1889. https://doi.org/10.1017/S0031182016001268

Kuriakose, S., \& J. E. Uzonna. 2014. Diminazene aceturate (Berenil), a new use for an old compound. Int. Immunopharmacol. 21:342-345. https://doi.org/10.1016/j. intimp.2014.05.027

Luckins, A. G., \& R. H. Dwinger. 2004. Non-tsetse transmitted animal trypanosomiasis. In: The Trypanosomiases. CABI publishing. 269:282. https://doi. org/10.1079/9780851994758.0269

Mastra, I.K. 2011. Seroprevalensi trypanosomiasis di Pulau Sumbawa Propinsi Nusa Tenggara Barat. Bul. Vet. BBVet Denpasar XXIII:131-138.

Metanaway-El, T. M. Nadia, M. El-Beih, T. A. Abdel, M. S. Hassanane, \& T. H. Aziz. 2009. Comparative studies on diagnosis of Trypanosoma evansi in horses. Turk. J. Vet. Anim. Sci. 34:85-90.

Muhanguzi, D., W. O. Okello, J. D. Kabasa, C. Waiswa, S. C. Welburn, \& A. P. M. Shaw. 2015. Cost analysis of option for management of Africa animal trypanosomiasis using interventions targeted at cattle in Tororo District; South-Eastern Uganda. Parasites Vectors. 8:1-9. https://doi. org/10.1186/s13071-015-0998-8

Muieed, M.A., Z. I. Chaudhary, \& A. R. Shakoori. 2010. Comparative studies on the sensitivity of polymerase chain reaction (PCR) and microscopic examination for the detection of Trypanosoma evansi in horses. Turkish J. Vet. Anim. Sci. 34:507-512.

Ngumbi. A. F, \& R. S. Silayo. 2017. A cross-sectional study on the use and misuse of trypanocides in selected pastoral and agropastoral areas of eastern and northeastern Tanzania. Parasites \& vectors. 10(607):1-9

[OIE]. 2012. Organization Internationale de Epizootic. Trypanosoma evansi infection. OIE Terrestial Manual Chapter 2.1.17. https://doi.org/10.1080/01652176.1986.969 4049

Partoutomo, S., M. Soleh, F. Politedy, A. Day, A. J. Wilson, \& 
D. B. Copeman. 1995. Studi patogenesis Trypanosoma evansi pada kerbau, sapi Friesian Holstein dan sapi peranakan ongole. J. Ilmu Ternak dan Vet. 1:41-48.

Payne, R.C., I. P. Sukamto, D. Djauhari, S. Partoutomo, T. W. Jone,A. J. Luckin, \& R. Boid.1991. Trypanosoma evansi infection in cattle, buffalo, and horses in Indonesia. Vet. Pathol. 38:253-256. https://doi.org/10.1016/0304-4017(91)90135-I

Powar R, V. Shegokar, P. Joshi, V. Dani, N. Tankhiwale, \& P. Truc. 2006. A rare case of human trypanosomiasis caused by Trypanosoma evansi. Indian J. Microbiol. 24:72-74. https:// doi.org/10.4103/0255-0857.19904

Rushton, J., P. K. Thornton, \& M. J. Otte. 1999. Methods of economic impact assessment. Rev. Sci. Tech. Int. Epiz. 18:315342. https://doi.org/10.20506/rst.18.2.1172

Salifu, A.W., S. A. Brempong, \& R. Alhassan. 2010. Benefit-cost analys and socio-economic consideration of trypanosomiasis control and treatment in Northern Ghana. African J. Agr. Res. 5:2281-2288.

Seidl, A., A. S. Moraes, R. Aquilar, \& M. S. Silva. 1998. A financial analysis of treatment strategies for Trypanosoma evansi in Brazilian Pantanal. Prevent Vet. Med. 33:219-234.

Sukanto, I. P., L. Solihat, F. Politedy, M. Dachlan, A. H. Wardhana, \& E. Satria. 2000. Peran diptera hemafagus sebagai vektor Trypanosoma evansi. Seminar nasional peternakan dan veteriner. 2000 Sep 18-19; Bogor, Indonesia. Pusbanglitnak, Bogor. hlm 481-487.

Tejedor-Junco, M. T., M. Gonzales, N. F. Rodriguez, J. A. Corbera, \& C. Gutierrez. 2011. Polymerase chain reaction (PCR) to detect T. evansi in experimentally inoculated goats.
Small Ruminant Res. 96:70-72. https://doi.org/10.1016/j. smallrumres.2010.10.014

The Livestock Service of Sumba Timur. 2010. East Sumba Livestock Service Annual Report 2010. NTT (ID): East Sumba Regional Government, East Nusa Tenggara-Indonesia.

The Livestock Service of Sumba Timur. 2011. East Sumba Livestock Service Annual Report 2011. NTT (ID): East Sumba Regional Government, East Nusa Tenggara-Indonesia.

The Livestock Service of Sumba Timur. 2012. East Sumba Livestock Service Annual Report 2012. NTT (ID): East Sumba Regional Government, East Nusa Tenggara-Indonesia.

The Livestock Service of Sumba Timur. 2013. East Sumba Livestock Service Annual Report 2013. NTT (ID): East Sumba Regional Government, East Nusa Tenggara-Indonesia.

The Livestock Service of Sumba Timur. 2014. East Sumba Livestock Service Annual Report 2014. NTT (ID): East Sumba Regional Government, East Nusa Tenggara-Indonesia.

The Livestock Service of Sumba Timur. 2015. East Sumba Livestock Service Annual Report 2015. NTT (ID): East Sumba Regional Government, East Nusa Tenggara-Indonesia.

The Livestock Service of Sumba Timur. 2016. East Sumba Livestock Service Annual Report 2016. NTT (ID): East Sumba Regional Government, East Nusa Tenggara-Indonesia. 